\title{
USING SOWING DATE MODIFICATION AND GENETIC RESISTANCE TO MANAGE SUNFLOWER BROOMRAPE (Orobanche cumana Wallr.)*
}

\author{
Akhtouch, B. ${ }^{1}$, Molinero-Ruiz, L. ${ }^{1}$, Dominguez, $\mathrm{J}^{2}$, \\ Melero-Vara, J.M. ${ }^{1}$ and Fernández-Martínez, J.M. ${ }^{1 * *}$ \\ ${ }^{1}$ Institute for Sustainable Agriculture, CSIC, Apdo. 4084, 14080 Córdoba, Spain \\ 2 IFAPA Centro Alameda del Obispo, CAPMA (Junta de Andalucía), \\ Apdo 3092, 14080 Córdoba, Spain
}

Received: October 25, 2013

Accepted: December 05, 2013

\section{SUMMARY}

The parasitic weed Orobanche cumana Wallr. (broomrape) constraints sunflower production in eastern and southern Europe and in the Middle East. Resistance of sunflower hybrids to $O$. cumana race $\mathrm{F}$, which is widespread in the main sunflower growing countries including Spain, is not complete. The infection of six populations of $O$. cumana (races B and F) in four sunflower genotypes in greenhouse $\left(10\right.$ to $\left.32^{\circ} \mathrm{C}\right)$ and in growth chamber $\left(20\right.$ to $\left.25^{\circ} \mathrm{C}\right)$ was studied. Also the effect of four sowing dates (SD) on the intensity of the attack of sunflower genotypes by $O$. cumana race $\mathrm{F}$ at three inoculum densities was investigated in an irrigated field in 2000 and 2001. Greenhouse was more favorable than growth chamber for $O$. cumana infection, which was highest by race $\mathrm{F}$ populations. In the field experiment, the reduction of the attack in the moderately resistant hybrid was significant at all SD and higher at late SD as compared to early sowings in both growing seasons. Late sowings (from the end of March until the beginning of April) favor an enhanced expression of the resistance of sunflower to $O$. cumana race $F$ irrespective of seedbank, and can be therefore recommended, under irrigation and together with the use of moderately resistant sunflower hybrids, as part of an efficient strategy on the control of this parasitic weed.

Key words: broomrape races, cultural control methods, genes of resistance, Helianthus annuus, parasitic plants, sunflower protection

\section{INTRODUCTION}

The chlorophyll-lacking parasitic weed Orobanche cumana Wallr. infects sunflower (Helianthus annuus L.) roots and depletes the plant of nutrients and water,

* This work is part of the PhD Thesis Dissertation of first author at the University of Córdoba, Spain.

** Corresponding author: jfernandezm@ias.csic.es 
causing severe crop losses in most countries of the Middle East and eastern and southern Europe. Within Orobanche spp., O. cumana is the only species that exhibits a clear race structure with respect to sunflower genotypes. Single major genes $\left(\mathrm{Or}_{1}\right.$ to $\left.\mathrm{Or}_{5}\right)$ were reported to confer resistance to races A to E of O. cumana (Vrânceanu et al., 1980). Parasite populations which overcome the resistance gene $\mathrm{Or}_{5}$ (race F) were identified in Spain in the mid 90's (Saavedra del Río et al., 1994). Race $\mathrm{F}$ is widespread in the main sunflower growing areas of the country since then (Molinero-Ruiz et al., 2009). Genetic resistance is the most effective and feasible control method against $O$. cumana, but complete immunity of sunflower hybrids to race $\mathrm{F}$ is infrequently expressed in the field; instead moderate resistance of the hybrids is observed (Molinero-Ruiz et al., 2008; 2009). Also imidazolinone herbicides can be very effective, but they must be applied to imidazolinone-resistant sunflowers (Clearfield production system) (Tan et al., 2005). Therefore, strategies for the control of $O$. cumana race $\mathrm{F}$ must be implemented aiming at improving sunflower performance in infested areas of the Mediterranean Basin (Fernández-Martínez et al., 2009).

Field studies on winter legumes in the Mediterranean area showed that a delay of the sowing date (from October and until January) was related to a decrease of the number of attached parasite plants of the crenate broomrape (O. crenata) (Mesa-García and García-Torres, 1986; Rubiales et al., 2003). Drought is a limiting factor for crop production under the semiarid Mediterranean climatic conditions of southern Spain. Therefore, early sunflower sowings (before February) yield better than late sowings (April) due to an optimization of crop water use efficiency and to the escape of the plants from high temperatures at the end of the growth cycle (Gimeno et al., 1989). As for the effect of the sowing date on the attacks of sunflower by $O$. cumana in this area, contradictory results have been reported. While Castejón-Muñoz et al. (1993) observed low levels of infection of confectionary sunflower in early sowing dates, other authors suggested that early sowing favored both the incidence of $O$. cumana and the degree of broomrape attack in sunflower genotypes (Alvarado-Aldea et al., 1998).

Modifications of the sowing date cause altered environmental conditions that affect Orobanche spp. development and its establishment in the host plant. A preconditioning period in a warm moist environment is required before dormancy of Orobanche spp. seeds is broken and they become responsive to germination stimulants (Joel et al., 1995; Song et al., 2005). Late sowing dates were associated to a reduction of broomrape infection in winter legumes because low temperatures delayed the end of seed dormancy and decreased germination of $O$. crenata (MesaGarcía and García-Torres, 1986; Van Hezewijk et al., 1994; López-Granados and García-Torres, 1996). Seeds of O. cumana stored outside the host rhizosphere may remain dormant and infective in the absence of any pre-conditioning for at least 17 years (Molinero-Ruiz et al., 2008). Also, the different effect of thermal regimes on the infection of genotypes of sunflower by $O$. cumana under controlled conditions 
has been reported (Sukno et al., 2001). Most of the sunflower genotypes tested by Sukno et al. (2001) had highest degree of attack by broomrape when the incubation temperature was $19^{\circ} \mathrm{C}$. Infections consisted on small nodules which did not develop to emerged broomrapes at 23 and $27^{\circ} \mathrm{C}$, and a delay in the emergence of broomrape was observed at $15^{\circ} \mathrm{C}$ (Sukno et al., 2001).

Aiming a more effective and sustainable control of $O$. cumana in sunflower, new strategies must be explored. Among them, and because immunity of commercial hybrids to race $\mathrm{F}$ of $O$. cumana is uncommon (Molinero-Ruiz et al., 2009; 2014), the combination of genetic resistance together with the shift of sowing date may have an effect on the reduction of the crop infection. Our work hypothesis was that the modification of the date of sowing can influence the establishment and development of $O$. cumana in moderately resistant sunflower. The objectives of this work were:

1) to compare the effect of different environments (growth chamber and greenhouse) on the degree of the attack of resistant and susceptible sunflower genotypes by $O$. cumana populations, and

2) to study the effect of different sowing dates on the infection of $O$. cumana race $\mathrm{F}$ in different genotypes of sunflower genotypes under field conditions.

\section{MATERIALS AND METHODS}

\section{Infection of sunflower by $O$. cumana under controlled conditions}

The effect of different environments on the infection of sunflower genotypes carrying different sources of resistance to $O$. cumana were investigated in one experiment that was twice conducted in greenhouse and in a growth chamber with controlled conditions. Seed from six populations of $O$. cumana were collected in the main growing areas of sunflower in central (CU996) and southern (CO197, SE395, SE296, SE198 and SE498) Spain between 1995 and 1998, and yearly increased on the susceptible confectionary inbred line B1 17 (Molinero-Ruiz et al., 2008). Orobanche cumana seed was collected at full maturity of broomrape plants, air-dried, separated from plant debris with a $500 \mu \mathrm{m}$ sieve and recovered on a 200 $\mu \mathrm{m}$ sieve, and stored in glass jars kept in the dark at room temperature (15 to $26^{\circ} \mathrm{C}$ ) until used.

Four sunflower genotypes were used: Kruglik A-41, J8281, Turbo and P96. The inbred lines Kruglik A-41 and J8281 carry the genes Or $_{1}$ (resistance to race A) and $\mathrm{Or}_{2}$ (resistance to race B) respectively, and are used as tester lines for races A and B of O. cumana (differentials) (Vrânceanu et al., 1980). The hybrid Turbo carries the $\mathrm{Or}_{5}$ gene conferring resistance to race $\mathrm{E}$ of the parasite and is susceptible to race $\mathrm{F}$ (García-Ruiz, 2000). The inbred line P96 is the differential for race G, since it is resistant to races $A$ to $F$ and susceptible to race $G$ (Molinero-Ruiz et al., 2008). Table 1 summarizes the sunflower genotypes used in this work as well as their reaction to races of $O$. cumana and the experiments in which they were included. 
Table 1: Genotypes of sunflower used in this work, their reaction to races of Orobanche cumana and experiments in which they were included

\begin{tabular}{lcccccccc}
\hline \multirow{2}{*}{ Name (type) } & \multicolumn{7}{c}{ Races of O. cumana } & \multirow{2}{*}{ Experiment } \\
\cline { 2 - 7 } & $\mathrm{A}$ & $\mathrm{B}$ & $\mathrm{C}$ & $\mathrm{D}$ & $\mathrm{E}$ & $\mathrm{F}$ & $\mathrm{G}$ & \\
\hline Kruglik A-41 (inbred line) & $\mathrm{R}^{\mathrm{a}}$ & $\mathrm{S}$ & $\mathrm{S}$ & $\mathrm{S}$ & $\mathrm{S}$ & $\mathrm{S}$ & $\mathrm{S}$ & Controlled conditions \\
J8281 (inbred line) & $\mathrm{R}$ & $\mathrm{R}$ & $\mathrm{S}$ & $\mathrm{S}$ & $\mathrm{S}$ & $\mathrm{S}$ & $\mathrm{S}$ & Controlled conditions \\
NR5 (inbred line) & $\mathrm{R}$ & $\mathrm{R}$ & $\mathrm{R}$ & $\mathrm{R}$ & $\mathrm{R}$ & $\mathrm{S}$ & $\mathrm{S}$ & Field \\
P96 (inbred line) & $\mathrm{R}$ & $\mathrm{R}$ & $\mathrm{R}$ & $\mathrm{R}$ & $\mathrm{R}$ & $\mathrm{R}$ & $\mathrm{S}$ & Controlled conditions \& field \\
Turbo (hybrid) & $\mathrm{R}$ & $\mathrm{R}$ & $\mathrm{R}$ & $\mathrm{R}$ & $\mathrm{R}$ & $\mathrm{S}$ & $\mathrm{S}$ & Controlled conditions \\
Rodrigo (hybrid) & $\mathrm{R}$ & $\mathrm{R}$ & $\mathrm{R}$ & $\mathrm{R}$ & $\mathrm{R}$ & $\mathrm{R}^{\star}$ & $\mathrm{S}$ & Field \\
\hline
\end{tabular}

${ }^{a} \mathrm{R}=$ resistance, $\mathrm{S}=$ susceptibility, $\mathrm{R}^{\star}=$ moderate resistance

Sunflower seeds were surface-sterilized by immersing them in $10 \%$ sodium hypochlorite for 5 to 10 minutes, then thoroughly rinsed in deionized water and incubated in the dark at saturation humidity in a germinator at 24 to $28^{\circ} \mathrm{C}$ until radicles were 2 to $5 \mathrm{~mm}$ long. Five seedlings (replications) of each of the genotypes were inoculated with each of the populations of $O$. cumana and arranged in a splitsplit-plot completely randomized design with one plant as experimental unit. Environment (growth chamber or greenhouse) was assigned to main factor, and populations and genotypes were assigned to secondary and tertiary factors respectively. Inoculations were performed by transplanting individual sunflower seedlings to pots with $80 \mathrm{~g}$ of perlite uniformly infested with $18 \mathrm{mg}$ of parasite seed and grown in chamber of controlled conditions set at 20 to $25^{\circ} \mathrm{C}$ or in greenhouse at 10 to $32^{\circ} \mathrm{C}$ (both with photoperiod of 14 hours/day). After growing for two weeks, plants were transplanted, with the infested soil, to 5-L pots containing SSPM soil mixture (sand : silt : peat moss, $2: 1: 2, \mathrm{~V} / \mathrm{V}$ ) and grown under the same conditions (growth chamber or greenhouse) until physiological maturity (10 to 12 weeks). Plants were fertilized three times a week with $500 \mathrm{ml}$ of complete nutrient solution (Hoagland and Arnon, 1950) per pot, and watered as required.

Reactions of sunflower were assessed at the end of the experiment by recording the final degree of attack (FDA) as the average final number of emerged O. cumana stems per sunflower plant. As no significant differences were found for FDA, data were pooled across experiments. Analysis of variance (ANOVA) was conducted on data of FDA transformed according to Ln (FDA+1). When significant differences were found for environment, populations, genotypes or for their interactions, comparisons were performed by means of Fisher's protected least significant difference (LSD) tests $(P=0.05)$. Data were statistically analyzed using Statistix v. 8.0 (Analytical Software, Tallahassee, FL, USA).

\section{Infection of sunflower by $O$. cumana under field conditions}

The assessment of the effect of the date of sowing on the infection of sunflower by the race $\mathrm{F}$ of $O$. cumana was performed in one experiment that was conducted in 2000 and 2001. In both seasons the experiment site was established in southern 
Spain (Córdoba) (3751'42" N and 0448'00" W). Four sowing dates (SD), approximately every 20 days, were compared in both years: February 17 (SD1), March 6 (SD2), March 27 (SD3) and April 6 (SD4). Population SE296 was used at three inoculum densities (ID) $(12.5,25$ and $50 \mathrm{mg}$ of broomrape seeds per sunflower plant). Three sunflower genotypes were used: the inbred lines NR5 and P96, which are susceptible and resistant differentials for $O$. cumana race $F$ respectively (Fernández-Martínez et al., 2004; Molinero-Ruiz et al., 2006) and Rodrigo, a commercial hybrid which is moderately resistant to race F (García-Ruiz, 2001). Sunflower seeds were surface-sterilized and induced to germinate following the methodology described in the previous subsection. Small pots $(7 \times 7 \times 8)$ were filled with $180 \mathrm{~g}$ of SSPM that had been homogeneously infested with broomrape seeds at the corresponding ID. Sunflower seedlings were individually planted in each of the pots, grown in shadehouse for 15 days and then transplanted with the soil mixture to the experimental field. Soil was previously tilled and prepared for furrow irrigation. Hand-weeding was performed when necessary for weed control in both experimental seasons.

Each year the experiment was set up as a split-split-plot arranged in a randomized complete block design with four blocks, SD as main factor, genotype as secondary factor and ID as tertiary factor. The design was combined over years as random effect, with SD, genotype and ID fixed effects (McIntosh, 1983). The experimental unit consisted of one row of 15 plants $0.2 \mathrm{~m}$ apart. The FDA as well as the incidence of broomrape (BI, percentage of sunflower plants with emerged stems of O. cumana) were recorded at the end of the crop cycle. The inbred lines NR5 and P96 had BI values of 100 (complete susceptibility) and 0\% (complete resistance) respectively, but high BI of slightly infected sunflower plants were observed in Rodrigo. Since no replicated data of $\mathrm{BI}$ were available, and trying to correctly characterize and assess the moderate resistance of Rodrigo, the intensity of the attack (IA) was statistically analyzed, being $\mathrm{IA}=(\mathrm{BI} / 100) \times \mathrm{FDA}$. No yield data were recorded because productions of the genotypes were not comparable - Rodrigo is a productive and commercial hybrid while NR5 and P96 are inbred lines used as donors of resistance to race $\mathrm{F}$.

Data transformation of IA according to $\log (\mathrm{IA}+1)$ was performed prior to ANOVA. When significant differences were found for the ID, values of IA were subjected to multiple regression analysis. Fisher's protected LSD tests $(P=0.05)$ were used for comparisons of SD, genotypes, years and their interactions. Statistical analyses of data were performed using Statistix v. 9.0.

\section{RESULTS}

\section{Infection of sunflower by $O$. cumana under controlled conditions}

The infection (FDA) of sunflower by $O$. cumana depended significantly on environment $(P=0.0001)$, sunflower genotype and $O$. cumana population $(P<0.0001$ 
both). Also the interactions environment $\times$ genotype, environment $\times$ population and genotype $\times$ population had a significant effect on FDA $(P \leq 0.0031)$.

Greenhouse was more favorable for $O$. cumana infection than controlled conditions in growth chamber ( 4.8 and 1.9 broomrape stems per sunflower plant respectively, averaged across genotypes and populations) (Figures 1a, b). The inbred line P96 was fully resistant to all the populations of $O$. cumana in both environments, and genotypes J8281 and Turbo had significantly higher values of infection than Kruglik A-41 (5.1 and 4.7, and 3.5 broomrape stems per sunflower plant respectively, averaged for environments and for populations) (Figures 1a, b).

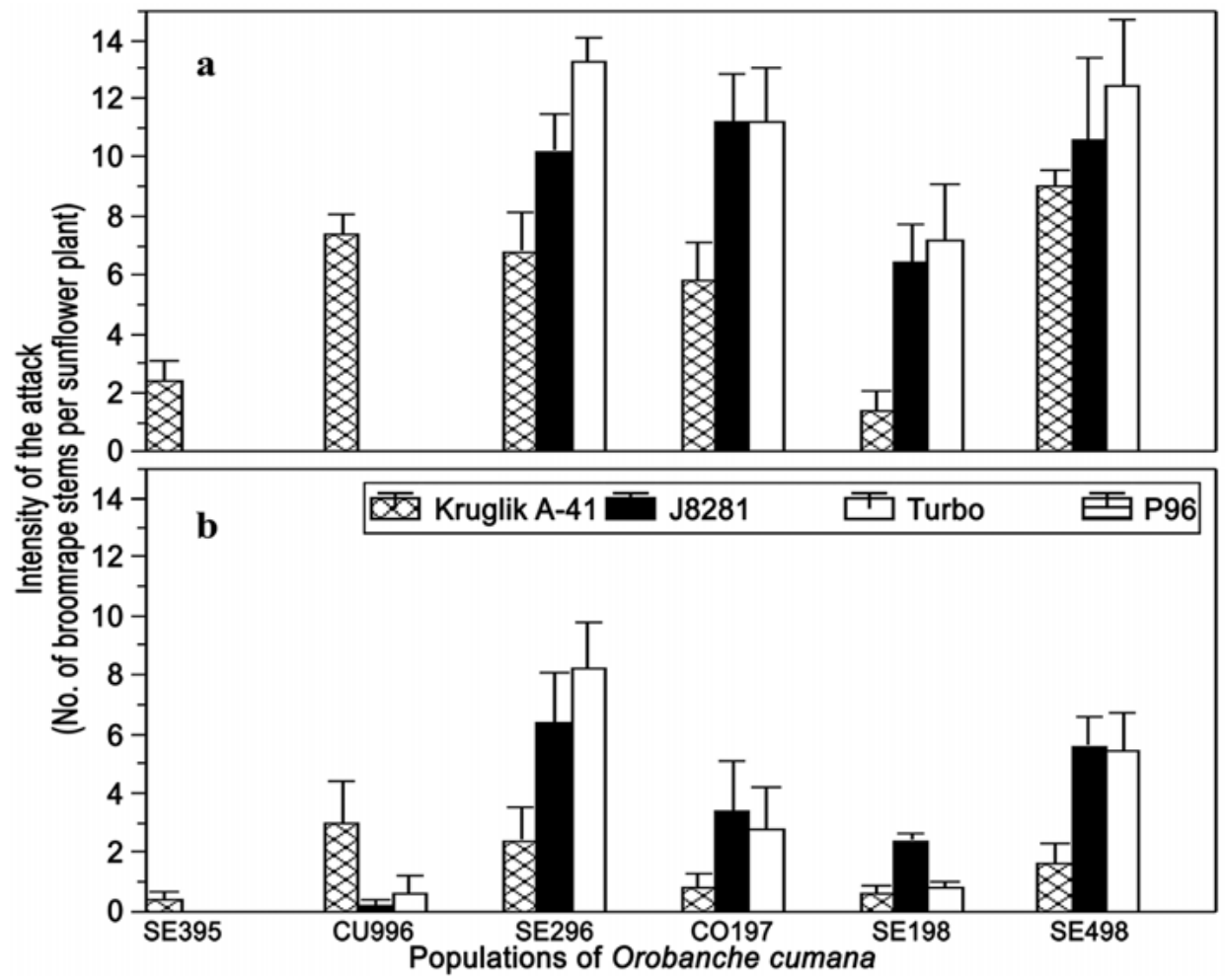

Figure 1: Final degree of attack by six populations of Orobanche cumana in four sunflower genotypes with resistance to the parasite under two different environments: greenhouse at 10 to $32^{\circ} \mathrm{C}$ (a) and chamber of controlled conditions at 20 to $25^{\circ} \mathrm{C}$ (b), both with photoperiod of 14 hours/day. Vertical upper bars represent the standard error of the mean of five replications over two experiments $(n=10)$.

When the interaction genotype $\times$ population was analyzed, J8281 and Turbo showed a higher susceptibility to SE296, CO197, SE198 and SE498 as compared to Kruglik A-41 in both greenhouse (Figure 1a) and growth chamber (Figure 1b). Populations CO197, SE198 and SE498 were identified as race F because they were not controlled by $\mathrm{Or}_{5}$ in Turbo. Population SE296, previously identified as race F 
(Akhtouch et al., 2002), was selected for the subsequent field experiment because it exhibited a good infectivity in both environments (Figure 2b). Populations SE395 and CU996 only infected Kruglik A-41 (1.4 and 5.2 broomrape stems per sunflower plant averaged across environments, respectively). Therefore they were characterized as race B. Infections by these populations were moderate in greenhouse (Figure 1a) and low in growth chamber (Figure 1b).

Concerning the interaction genotype $\times$ environment, no significant differences of FDA between Turbo, J8281 and Kruglik A-41 were obtained in greenhouse (average 6.4 broomrape stems per sunflower plant across populations and genotypes). Kruglik A-41 had a lower susceptibility in the chamber ( 1.5 broomrape stems per sunflower plant averaged across populations) as compared to the one of Turbo and J8281 in this same environment (3 broomrape stems per sunflower plant averaged across populations and genotypes) (Figure 2a). As previously mentioned, P96 was not infected neither in greenhouse nor in growth chamber.

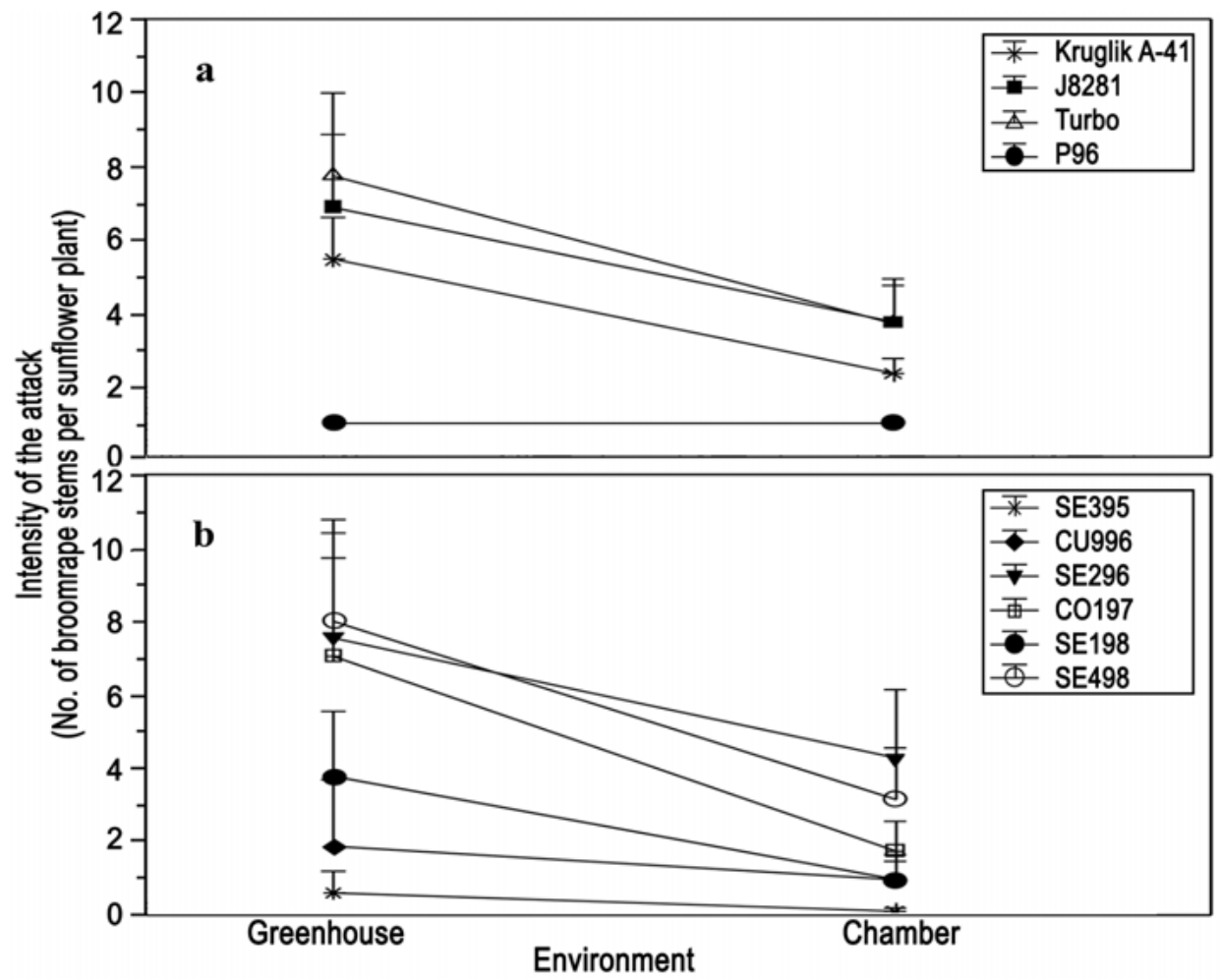

Figure 2: Effect of the environment (greenhouse or chamber of controlled conditions) on the infection of four sunflower genotypes (critical least significant difference value for environment $\times$ genotype $=0.5$ ) $(a)$, and caused by six populations of Orobanche cumana (critical least significant difference value for environment $\times$ population $=0.8)(b)$, expressed as final degree of attack. 
Finally, when the effect of the environment on the infectivity of $O$. cumana was considered (environment $\times$ population), SE296, CO197 and SE498 showed similar and high values of FDA in greenhouse (average 7.5 O. cumana stems per sunflower plant across genotypes), and moderate (SE296 and SE498) or low (CO197) levels in growth chamber (averages 3.7 and 1.7 O. cumana stems per sunflower plant respectively, across genotypes) (Figure 2b). Statistical differences were also found between the infectivity of SE198 in both environments: 3.7 and 0.9 O. cumana stems per sunflower plant averaged across genotypes, in greenhouse and growth chamber respectively (Figure $2 b$ ).

\section{Weather conditions}

Maximal, minimal and mean daily air temperatures from mid February to the end of May were in the range of the long-term regional average during both growing seasons, although milder conditions occurred in 2000 as compared to 2001. Average maximal temperature was $0.4^{\circ} \mathrm{C}$ higher in 2001 as compared to 2000 . On the contrary, average minimal temperature was $0.4^{\circ} \mathrm{C}$ higher in 2000 than in 2001 . A slight difference of $0.2^{\circ} \mathrm{C}$ was recorded between averaged mean temperatures along the period in both seasons (Figure 3). Rainfall measured from September 1999 to June 2000 was $313 \mathrm{~mm}$. The experiment received $469 \mathrm{~mm}$ of rainfall along the same monthly period in the following season. Two furrow irrigations of $500 \mathrm{~mm}$ each were applied to sunflower before flowering and at maturity in both seasons. Therefore the total water input (rainfall plus irrigation) amounted to $1313 \mathrm{~mm}$ in 2000 and $1469 \mathrm{~mm}$ in 2001.

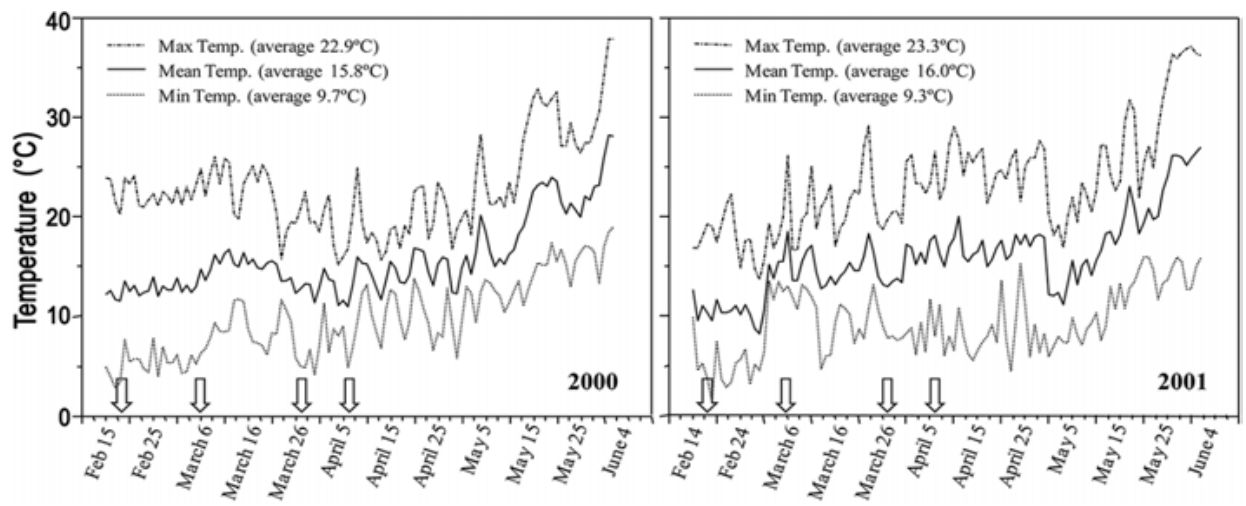

Figure 3: Maximal, minimal and mean daily air temperatures from Feb 15 and 14, to June 4 in 2000 and 2001 respectively. The four sowing dates in each season are indicated with arrows.

\section{Infection of sunflower by $O$. cumana under field conditions}

Significant effects of the sources of variation in the ANOVA model for the combined experiment are presented in Table 2. The IA by $O$. cumana for years, SD, ID and genotypes is presented in Table 3. 
Broomrape attacks were significantly $(P=0.0072)$ more intense in 2001 as compared to 2000. Concerning the inoculum densities, a significant $(P=0.0404)$ effect on the occurred. Since significant $(P=0.0008)$ differences of IA were also found for genotypes, the continuous course of IA with ID was independently analyzed in NR5 and Rodrigo. The attack of $O$. cumana in P96 was zero irrespective of ID and SD. The best fits of data were obtained as quadratic functions of IA with ID (Figure 4).

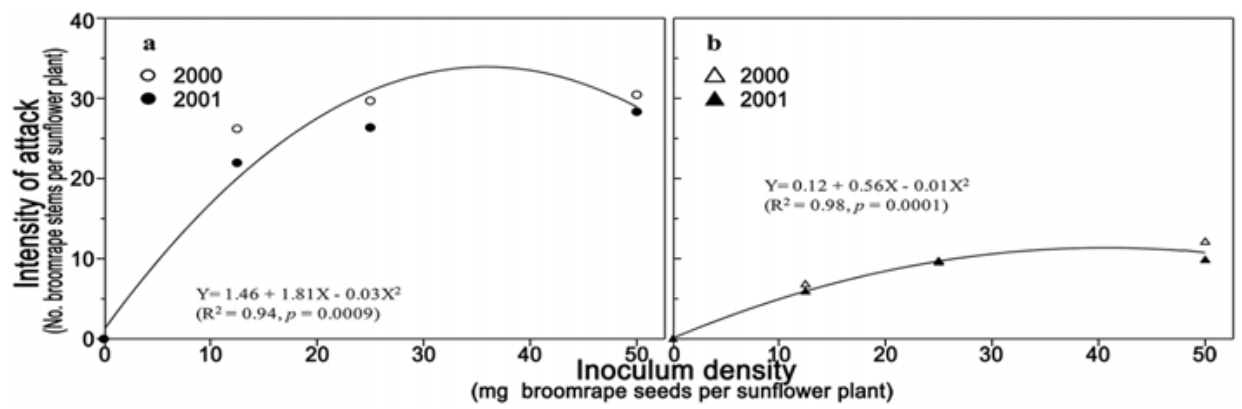

Figure 4: Intensity of the attack of sunflower inbred line NR5 (a) and hybrid Rodrigo (b) by Orobanche cumana race $F$ in field experiments conducted in 2000 and 2001 as a function of inoculum density.

Table 2: Analysis of variance to test the effect of year, sowing date, and inoculum density of Orobanche cumana on the intensity of the attack by the parasite in three genotypes of sunflower

\begin{tabular}{|c|c|c|c|c|c|}
\hline Sources of variation ${ }^{a}$ & $\mathrm{df}$ & MS & \multicolumn{2}{|c|}{$F$} & $P$ \\
\hline Year $(\mathrm{Y})$ & 1 & M1 & M1/M2 & 15.8900 & 0.0072 \\
\hline Year / Block (Y / B) & 6 & M2 & & & \\
\hline Sowing date (SD) & 3 & M3 & M3/M4 & 9.2961 & 0.0459 \\
\hline $\mathrm{Y} \times \mathrm{SD}$ & 3 & M4 & M4/M5 & 7.9336 & 0.0014 \\
\hline $\mathrm{Y} \times \mathrm{B} \times \mathrm{SD}$ & 18 & M5 & & & \\
\hline Genotype (G) & 2 & M6 & M6/M7 & 1237.4271 & 0.0008 \\
\hline$Y \times G$ & 2 & M7 & M7/M9 & 4.1458 & 0.0423 \\
\hline$Y \times B \times G$ & 12 & M9 & & & \\
\hline$S D \times G$ & 6 & M8 & M8/M11 & 45.3228 & 0.0000 \\
\hline $\mathrm{Y} \times \mathrm{SD} \times \mathrm{G}$ & 6 & M10 & M10/M11 & 5.3307 & 0.0005 \\
\hline $\mathrm{Y} \times \mathrm{B} \times \mathrm{SD} \times \mathrm{G}$ & 36 & M11 & & & \\
\hline Inoculum density (ID) & 2 & M12 & M12/M13 & 23.7686 & 0.0404 \\
\hline $\mathrm{Y} \times \mathrm{ID}$ & 2 & M13 & M13/M20 & 1.4565 & 0.2365 \\
\hline $\mathrm{SD} \times \mathrm{ID}$ & 6 & M14 & M14/M16 & 1.1068 & 0.4526 \\
\hline$G \times I D$ & 4 & M15 & M15/M17 & 5.3054 & 0.0675 \\
\hline$Y \times S D \times I D$ & 6 & M16 & M16/M20 & 2.2391 & 0.0427 \\
\hline$Y \times G \times I D$ & 4 & M17 & M17/M20 & 2.5978 & 0.0387 \\
\hline$S D \times G \times I D$ & 12 & M18 & M18/M19 & 0.4512 & 0.9088 \\
\hline$Y \times S D \times G \times I D$ & 12 & M19 & M19/M20 & 2.6739 & 0.0028 \\
\hline Pooled error b & 144 & M20 & & & \\
\hline Pooled error & 287 & & & & \\
\hline
\end{tabular}

${ }^{a}$ The field experiment was designed as a split-split-plot arranged in a randomised complete block design combined over years (random effect) with sowing date, genotype and inoculum density (fixed effects) as treatments (Mclntosh, 1983). 


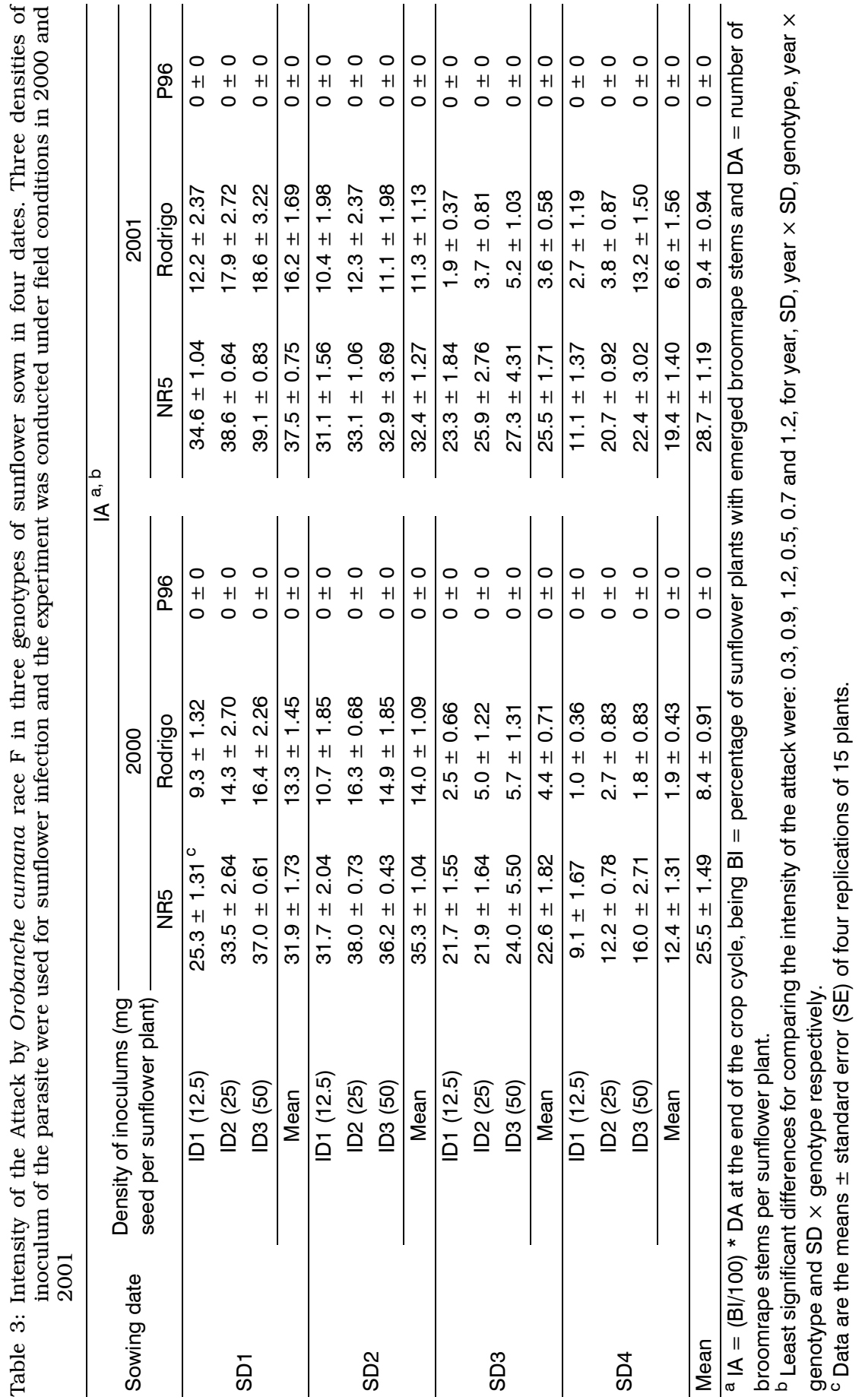


Significant differences of IA were found for SD as well $(P=0.0459)$, but most interesting were the significant interactions between years, SD, and/or genotypes $(P \leq 0.0427)$ (Table 2).

When the interaction year $\times$ SD was considered, early sowings (SD1 and SD2) were associated to the highest IA in both years (15.7 and 16.2 broomrape stems per sunflower plant averaged across ID, genotypes and SD for 2000 and 2001 respectively) (Table 3). In contrast, the lowest broomrape attacks were recorded for the latest sowing date (SD4) in 2000 (4.8 broomrape stems per sunflower averaged for ID and genotypes) (Table 3 and Figure 5).

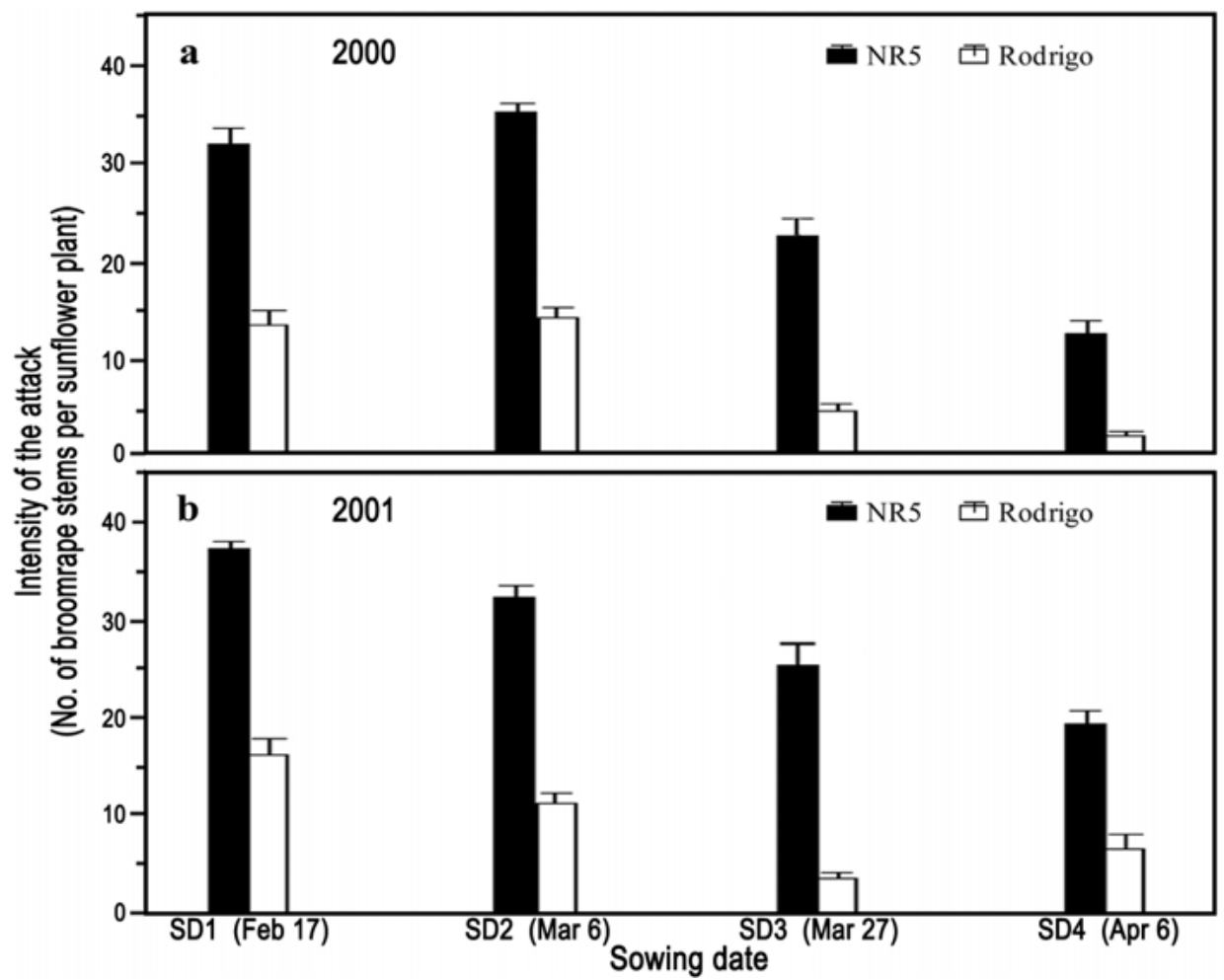

Figure 5: Effect of four different sowing dates on the intensity of the attack (IA) by Orobanche cumana race $F$ in sunflower genotypes with resistance to the parasite grown in irrigated field experiments. Since a significant effect of the interaction year $\times$ sowing date was obtained, the data are presented by years. The IA was calculated as $I A=($ broomrape incidence $/ 100) \times$ final degree of attack. Vertical upper bars represent the standard error of the mean of four replications of 15 plants and across the three ID $(n=12)$.

Concerning the interaction year $\times$ genotype, in both years the highest IA occurred on NR5, and IA was zero in P96 (Table 3). The moderate resistance of Rodrigo was shown by intermediate and significantly $(P=0.0423)$ different values of IA in 2000 and $2001-8.4$ and 9.4 broomrape stems per sunflower plant averaged across ID and SD, respectively (Table 3 ). 
Most interesting was the significant $(P<0.0001)$ interaction $\mathrm{SD} \times$ genotype. The highest infections occurred in NR5, although SD3, and mainly SD4, were related to low values of IA in this line (averages 24.0 and 15.9 broomrape stems per sunflower plant across years, respectively) (Figure 5).

The moderate resistance of Rodrigo was expressed through a significantly lower IA than the one in NR5 irrespective of SD. Even when Rodrigo was sown at the most favorable time for O. cumana infection (SD1 or SD2) the IA by the parasite was lower as compared to the one in NR5 (13.7 and 34.3 broomrape stems per sunflower plant averaged for SD1 and SD2 across ID and years, respectively) (Table 3). The level of control achieved by the moderate resistance of Rodrigo was highest at late sowing dates SD3 and SD4 (4.0 and 4.2 broomrape stems per sunflower plant averaged across ID and years, respectively) (Table 3).

\section{DISCUSSION AND CONCLUSIONS}

Delayed sowings have been recommended in order to prevent severe attacks of O. crenata in susceptible cultivars of winter legumes (Mesa-García and GarcíaTorres, 1986; Arjona-Berral et al., 1987; Rubiales et al., 2003), but early sowings are considered as part of an integrated control strategy of $O$. crenata when partially resistant cultivars are sown (Pérez-de-Luque et al., 2004). Under Mediterranean conditions, early sowing of spring sunflower was recommended for growing a very susceptible confectionary cultivar in moderately broomrape-infested areas (Castejón-Muñoz et al., 1993). Similarly, a delayed sowing date was found to be associated with increases in $O$. cumana infestation and yield losses in oilseed sunflower in Romania (Grenz et al., 2008). However, when oilseed cultivars of sunflower with resistance to $O$. cumana were early planted in Israel, their resistance was not expressed (Ish-Shalom-Gordon et al., 1994). The results of our work, in agreement with those of Alvarado-Aldea et al. (1998), suggest that the modification of the SD affects differently the natural infection by $O$. cumana in susceptible and moderately resistant sunflower. While high and statistically similar attacks were observed in the susceptible genotype NR5 irrespective of the SD and of the ID in both growing seasons, the reduction of the attack in Rodrigo was significant at all SD and higher at late SD as compared to early sowings. The horizontal resistance of crops to parasites is highly affected by environmental conditions (Simmonds, 1991; McDonald and Linde, 2002; Stuthman et al., 2007; Wallwork, 2009). In fact, the strong effect of the environment on the expression of the resistance of sunflower hybris to $O$. cumana race $\mathrm{F}$ has been reported, with these hybrids yielding twice as much as susceptible ones under low water availability and high intensities of $O$. cumana attack (Molinero-Ruiz et al., 2009). From our results, we can conclude that a delay of sowing causes a shift of environmental conditions that can be associated to an enhanced expression of the moderate resistance of hybrids of sunflower against the race $\mathrm{F}$ of $O$. cumana under our conditions of sufficient water availability. The effect 
of a shift of sowing date on their performance in fields infested by O. cumana and under drought conditions as compared to irrigation might be investigated in the future.

On the other hand, we found that the response of IA to ID followed a quadratic response in both susceptible and moderately resistant genotypes. Previous field works have determined that the intensity of the attachment of O. cumana to susceptible sunflower versus ID fitted a rectangular hyperbolic function (Grentz et al., 2008). The different fitting obtained in both works could be due to differences in methodologies for host plants inoculation and ID quantification, as well as to different ranges of ID in each work. In any case, and in agreement Grenz et al. (2008), the negative response of IA to high ID could be due to competition between parasite seeds for the successful establishment in the host. According to our results in pot experiments (unpublished data), the competition between seeds of $O$. cumana at very high ID can importantly weaken the root system of the host at early growth stages, decreasing its vigor and therefore its potential to sustain a high number of full-grown plants of $O$. cumana. Of particular importance is the fact that in our work a quadratic equation fitted the response of IA to ID in the case of the moderately resistant genotype Rodrigo as well.

As mentioned, the modification of the SD is related to environmental changes under which the establishment and development of $O$. cumana in sunflower take place. Since our field experiments were conducted under irrigation, a shift of temperature conditions seem to be the major factor for the decrease of broomrape infection in the crop as SD is delayed. Moreover, it could also be related to the differential effect of the SD on the final broomrape infection in susceptible and resistant genotypes (significant interaction SD $\times$ genotype). In fact, Eizenberg et al. (2012) have recently validated a thermal time model based on the main role of temperature on the parasitism of $O$. cumana in susceptible irrigated sunflower in Israel. Therefore the relationship between $\mathrm{SD}$, temperature conditions (i.e. thermal time) and their effect on establishment, development and final field infection by $O$. cumana in moderately resistant sunflower should be explored in the future.

The strong influence of the temperature on different stages of the biological development of $O$. cumana under controlled conditions is widely documented (Nandula et al., 1996; Sukno et al., 2001; Eizenberg et al., 2003a, b; Ephrat and Eizenberg, 2010). In our work, temperatures of 10 to $32^{\circ} \mathrm{C}$ in the greenhouse provided a more conducive environment for $O$. cumana infection than 20 to $25^{\circ} \mathrm{C}$ in chamber. Since plants were watered as needed and a 14-h photoperiod was used in both environments, differences of FDA between both environments show, in accordance with our results from the field experiments, that temperature played the major role in the successful establishment and subsequent emergence of the parasite in the host. Surprisingly, greenhouse conditions favored the infection of populations of $O$. cumana belonging to race $\mathrm{F}$ but not the one of populations of the less virulent race B. Future research should explore the hypothesis that a fitness cost of the virulence 
is related to a low adaptability of $O$. cumana to environmental changes, as reported for other parasites (Zhan and McDonald, 2013).

Under Mediterranean conditions, early sunflower sowings are recommended in order to obtain yield increases provided by high water availability (Gimeno et al., 1989). However, the management of the crop might be different when $O$. cumana race $\mathrm{F}$ exists in the field. The planting of moderately resistant sunflower in highly infested fields and under dryland conditions has been reported, in spite of the development of some $O$. cumana plants in them, as a good control measure because of the good performance of these hybrids with low water availability and high parasite pressure (Molinero-Ruiz et al., 2009). Other authors have mentioned the benefit of using crop cultivars with moderate resistance to Orobanche spp. because they can slow down parasite development and prevent seed production (Pérez-de-Luque et al., 2004). The results of our work show that, under irrigation, late sowings (from the end of March until the beginning of April) of sunflower hybrids with moderate resistance to $O$. cumana race $\mathrm{F}$ hinder the establishment of the parasite irrespective of the infestation level, and can be therefore recommended as an efficient control method. Future works should address the advisability of late sowings when moderately resistant hybrids are grown under dryland conditions. Alternatively, and when levels of $O$. cumana infestation are low, growers might give priority to the increase of yield through high water availability. In this case very early or even winter sunflower planting might be convenient, but then the control of broomrape infections should be achieved with imidazolinone herbicides that must be applied to imidazolinone-resistant sunflowers. As a conclusion, our work shows that $O$. cumana race $\mathrm{F}$ can be efficiently controlled in irrigated sunflower through the use of moderately resistant hybrids and the delay of the sowing date, and constitutes a good example of combination of genetic and cultural methods in crop protection.

\section{ACKNOWLEDGEMENTS}

This work was partially supported by grants RTAO1-131 (National Institute for Agricultural Research, INIA) and PIE200940I120 (Spanish National Research Council, CSIC). B. Akhtouch was the recipient of a Grant from the Spanish Agency for International Development Cooperation (MAEC-AECID). Seeds of sunflower hybrid Rodrigo were a kind gift of Maribo Seed España SA. 


\section{REFERENCES}

Akhtouch, B., J. Muñoz-Ruz, J.M. Melero-Vara, J.M. Fernández-Martínez and J. Domínguez, 2002. Inheritance of resistance to race $\mathrm{F}$ of broomrape in sunflower lines of different origins. Plant Breed. 121: 266-268.

Alvarado-Aldea, J., J.A. García-Tejada and J.M. Melero-Vara, 1998. Interactions of host genotype and planting time in the infection of sunflower by Orobanche cernua. p.p. 27-31. In: Wegmann, K., Musselman, L.J. and Joel, D.M. (eds.), Current problems of Orobanche researches. Proc. $4^{\text {th }}$ International Workshop on Orobanche research. Albena, Bulgaria.

Arjona-Berral, A., J. Mesa-García and L. García-Torres. 1987. Phenology and growth of Orobanche crenata Forsk (broomrape) in four legume crops. Weed Res. 27: 349-360.

Castejón-Muñoz, M., F. Romero-Muñoz and L. García-Torres. 1993. Effect of planting date on broomrape (Orobanche cernua Loefl.) infections in sunflower (Helianthus annuus L.). Weed Res. 33: 171-176.

Eizenberg, H., J. Hershenhorn, D. Plakhine, Y. Kleifeld, D. Shtienberg and B. Rubin, $2003 a$. Effect of temperature on susceptibility of sunflower varieties to sunflower broomrape (Orobanche cumana) and Egyptian broomrape (Orobanche aegyptiaca). Weed Sci. 51: 279-286.

Eizenberg, H., D. Plakhine, J. Hershenhorn, Y. Kleifeld and B. Rubin, 2003b. Resistance to broomrape (Orobanche spp.) in sunflower (Helianthus annuus L.) is temperature dependent. J. Exp. Bot. 54: 1305-1311.

Eizenberg, H., J. Hershenhorn, G. Achdari and J.E. Ephrath, 2012. A thermal time model for predicting parasitism of Orobanche cumana in irrigated sunflower - Field validation. Field Crops Res. 137: 49-55.

Ephrath, J.E. and H. Eizenberg, 2010. Quantification of the dynamics of Orobanche cumana and Phelipanche aegyptiaca parasitism in confectionery sunflower. Weed Res. 50: 140152.

Fernández-Martínez, J.M., B. Pérez-Vich, B. Akhtouch, L. Velasco, J. Muñoz-Ruz, J.M. MeleroVara and J. Domínguez, 2004. Registration of four sunflower germplasms resistant to race $\mathrm{F}$ of broomrape. Crop Sci. 44: 1033-1034.

Fernández-Martínez, J.M., J. Domínguez, B. Pérez-Vich and L. Velasco, 2009. Current research strategies for sunflower broomrape control in Spain. Helia 32: 47-56.

García-Ruiz, R.J., 2000. Red Andaluza de Experimentación Agraria, Girasol: campaña 2000. CAP, Junta de Andalucía, Seville, Spain.

García-Ruiz, R.J., 2001. Red Andaluza de Experimentación Agraria, Girasol: campaña 2001. CAP, Junta de Andalucía, Seville, Spain.

Grenz, J.H., V.A. Istoc, A.M. Manschadi and J. Sauerborn, 2008. Interactions of sunflower (Helianthus annuus) and sunflower broomrape (Orobanche cumana) as affected by sowing date, resource supply and infestation level. Field Crops Res. 107: 170-179.

Gimeno, V., J.M. Fernández-Martínez and E. Fereres, 1989. Winter planting as a means of drought escape in sunflower. Field Crops Res. 22 (4): 307-316.

Hoagland, D.R. and D.I. Arnon, 1950. The water culture method for growing plants without soil, Circ. 347. Calif. Agr. Exp. Stn. USA.

Ish-Shalom-Gordon, N., R. Jacobsohn and Y. Cohen, 1994. Seasonal fluctuations in sunflowers resistance to Orobanche cumana. p.p. 351-355. In: Pieterse, A.H., Verkleijand, J.A.C. and Ter Borg, S.T. (eds.), Biology and management of Orobanche. Proc. $3^{\text {rd }}$ International Workshop on Orobanche and related Striga research. The Royal Tropical Institute, Amsterdam, The Netherlands.

Joel, D.M., J.C. Steffens and D.M. Matthews, 1995. Germination of weedy root parasites. p. 567-597. In: Kigel, J. and Galili, G. (eds.), Seed Development and Germination. CRC Press, London, United Kingdom.

López-Granados, F., and L. García-Torres, 1996. Effects of environmental factors on dormancy and germination of crenate broomrape (Orobanche crenata). Weed Sci. 44: 284-289.

McDonald, B. and C. Linde, 2002. Pathogen population genetics, evolutionary potential and durable resistance. Ann. Rev. Phytopathol. 40: 349-379.

McIntosh, M.S., 1983. Analysis of combined experiments. Agron. J. 75: 153-155.

Mesa-García, J. and L. García-Torres, 1986. Effect of planting date on parasitism of broad bean (Vicia faba) by crenate broomrape (Orobanche crenata). Weed Sci. 34: 544-550. 
Molinero-Ruiz, M.L., R. García-Ruiz, J.M. Melero-Vara and J. Domínguez, 2006. Pathogenic diversity within field populations of Orobanche cumana and different reactions on sunflower genotypes. Weed Res. 46: 462-469.

Molinero-Ruiz, M.L., B. Pérez-Vich, R. Pineda-Martos and J.M. Melero-Vara, 2008. Indigenous highly virulent accessions of the sunflower root parasitic weed Orobanche cumana. Weed Res. 48: 169-178.

Molinero-Ruiz, M.L., J.M. Melero-Vara, R. García-Ruiz and J. Domínguez, 2009. Orobanche cumana race $\mathrm{F}$ : performance of resistant sunflower hybrids and aggressiveness of populations of the parasitic weed. Weed Res. 49: 469-478.

Molinero-Ruiz, L., A.B. García-Carneros, M. Collado-Romero, S. Raranciuc, J. Domínguez and J.M. Melero-Vara, 2014. Pathogenic and molecular diversity in highly virulent populations of the parasitic weed Orobanche cumana (sunflower broomrape) from Europe. Weed Research, In Press.

Nandula, V.K., C.L. Foy and J.H. Westwood, 1996. Environmental influences on germination of Orobanche. p. 411-416. In: Moreno, M.T., Cubero, J.I., Berner, D., Joel, D., Musselman, L.J. and Parker, C. (eds.), Advances in Parasitic Plant Research, Proc. $6^{\text {th }}$ International Symposium of Parasitic Weeds. Seville, Spain. Junta de Andalucía, Seville.

Pérez-de-Luque, A., J.C. Sillero, A. Moral, J.I. Cubero and D. Rubiales, 2004. Effect of sowing date and host resistance on the establishment and development of Orobanche crenata in faba bean and common vetch. Weed Res. 44: 282-288.

Rubiales, D., C. Alcántara, A. Pérez-de-Luque, J. Gil and J.C. Sillero, 2003. Infection of chickpea (Cicer arietinum) by crenate broomrape (Orobanche crenata) as influenced by sowing date and weather conditions. Agronomie 23: 359-362.

Saavedra del Río, M., J.M. Fernández-Martínez and J.M. Melero-Vara, 1994. Virulence of populations of Orobanche cernua Loefl. attacking sunflower in Spain. p. 139-141. In: Pieterse, A.H., Verkleij, J.A.C. and ter Borg, S.T. (eds.), Biology and management of Orobanche. Proceedings of the $3^{\text {rd }}$ International Workshop on Orobanche and related Striga research, The Royal Tropical Institute. Amsterdam, The Netherlands.

Simmonds, N.W., 1991. Genetics of horizontal resistance to diseases of crops. Biological Reviews 66: 189-241.

Song, W.J., W.J. Zhou, Z.L. Jin, D.D. Cao, D.M. Joel, Y. Takeuchi and K. Yoneyama, 2005. Germination response of Orobanche seeds subjected to conditioning temperature, water potential and growth regulator treatments. Weed Res. 45: 467-476.

Stuthman, D.D., K.J. Leonard and J. Miller-Garvin, 2007. Breeding crops for durable resistance to disease. Advances in Agronomy 95: 319-367.

Sukno, S., Fernández-Martínez, J.M. and J.M. Melero-Vara, 2001. Temperature effects on the disease reactions of sunflower to infection by Orobanche cumana. Plant Dis. 85, 553-556.

Tan, S., R.R. Evans, M.L. Dahmer, B.K. Singh and D.L. Shaner, 2005. Imidazolinone-tolerant crops: history, current status and future. Pest Manag. Sci. 61: 246-257.

Van Hezewijk, M.J., K.H. Linker, F. Lopez-Granados, O.A. Al-Menoufi, L. Garcia-Torres, M.C. Saxena M.C., J.A.C. Verkleij and A.H. Pieterse, 1994. Seasonal changes in germination response of buried seeds of Orobanche crenata Forsk. Weed Res. 34: 369-376.

Vrânceanu, A.V., V.A. Tudor, F.M. Stoenescu and N. Pirvu, 1980. Virulence groups of Orobanche cumana Wallr., differential hosts and resistance source genes in sunflower. p. 74-82. In: Proc. $9^{\text {th }}$ International Sunflower Conference, Torremolinos, Spain, Int. Sunfl. Assoc., Paris.

Wallwork, H., 2009. The use of host plant resistance in disease control. p.p. 122-141. In: Walters, D. (ed.), Disease control in Crops, Wiley-Blackwell.

Zhan, J. and B.A. McDonald, 2013. Experimental measures of pathogen competition and relative fitness. Ann. Rev. Phytopathol. 51: 131-53. 


\title{
UTILIZACIÓN DE LA MODIFICACIÓN DE LA FECHA DE SIEMBRA Y LA RESISTENCIA GENÉTICA EN EL MANEJO DEL JOPO DE GIRASOL (Orobanche cumana Wallr.)
}

\author{
RESUMEN
}

La mala hierba parásita Orobanche cumana Wallr. (jopo) limita la producción de girasol en el este y sur de Europa y en el Medio Este. La resistencia de los híbridos de girasol a la raza $\mathrm{F}$ de $O$. cumana, que está ampliamente distribuida en los países productores de girasol, incluido España, no es completa. Se estudió, en invernadero $\left(10\right.$ a $\left.32^{\circ} \mathrm{C}\right)$ y en cámara de crecimiento $(20$ a $25^{\circ} \mathrm{C}$ ), la infección de seis poblaciones de $O$. cumana (razas B y F) en cuatro genotipos de girasol. También se investigó el efecto de cuatro fechas de siembra (SD) sobre la intensidad del ataque de genotipos de girasol por la raza $\mathrm{F}$ de O. cumana a tres densidades de inóculo, en campo y con riego, en 2000 y 2001. El invernadero fue más favorable que la cámara de crecimiento para la infección por $O$. cumana, la cual fue máxima en el caso de las poblaciones de raza F. En el experimento de campo se obtuvo una reducción significativa de la intensidad del ataque en el híbrido moderadamente resistente con todas las fechas de siembra y, en ambos años, la reducción fue mayor con siembras tardías en comparación a las siembras tempranas. Las siembras tardías (desde finales de marzo hasta principios de abril) favorecen un incremento en la expresión de la resistencia de girasol a la raza $\mathrm{F}$ de $O$. cumana independientemente de la cantidad de inóculo en el suelo, y pueden por lo tanto recomendarse, en condiciones de riego y junto con la siembra de híbridos de girasol moderadamente resistentes, como parte de una estrategia efectiva para controlar esta mala hierba parásita. 
